\title{
Manajemen Pengembangan Kompetensi Profesional Guru Pendidikan Jasmani Sekolah Menengah Atas (SMA) Negeri Di Kota Yogyakarta
}

\author{
Nur Azis Rohmansyah ${ }^{a}$, Setiyawan ${ }^{b}$ \\ ac PJKR, Universitas PGRI Semarang, Indonesia \\ "Corresponding author: nurazisrohmansyah30@gmail.com
}

ART I CLE INFO

Article history:

Received 05 April 2018

Received in revised form 12

April 2018

Accepted 25 April 2018

Keywords: Management, professional, sport education, teacher
A B S T R A C T

The purpose of this study is to describe the professionalism condition of high school teachers (SMA) in the city of Yogyakarta. The method used in this research used qualitative research method with case study type with observation data taking technique, interview, and document study. The study was conducted in Yogyakarta City by taking data in several senior high schools in Yogyakarta consisting of the headmaster, the head of MGMP Yogyakarta, and the sport education teacher who had met the criteria on the selection of informants. Data analysis technique using QSR NVivo Plus 11. The result of research of professionalism condition of sport education teacher in Yogyakarta city can not be said high, this is because there are still many problems that influence the level of professionalism of sport education teacher in Yogyakarta City, such as facilities and infrastructure which not yet adequate, Teaching that still uses conventional methods, and administrative flaws. Based on the above conclusions, the results of this study have implications of High School Teachers in all cities of Yogyakarta to further improve their competence through various ways to be more competent to be physical education teachers so as to channel knowledge useful and good for learners.

\section{Pendahuluan}

Pendidikan jasmani merupakan bagian penting dari proses pendidikan. Pendidikan jasmani (Penjas) adalah salah satu disiplin ilmu yang diberikan kepada peserta didik mulai dari awal proses pendidikan (sekolah dasar) sampai pada tingkat universitas. Tujuan mata pelajaran penjas adalah untuk mampu menerapkan pola hidup sehat, melatih keterampilan motorik serta mengajarkan peserta didik untuk memiliki semangat pantang menyerah, disiplin, sportif, dan menjalin komunikasi dengan lingkungannya.

Pengembangan guru merupakan suatu kewajiban guna terciptanya pembelajaran yang berkualitas. Hal ini dikarenakan untuk menjadi guru profesional memerlukan waktu yang panjang. Selain melakukan pengembangan yang dilakukan secara mandiri, pengembangan yang dilakukan oleh institusi pendidikan sangatlah penting. Seperti yang di amanatkan dalam Peraturan Pemerintah Nomor 74 Tahun 2005 tentang Guru disebutkan bahwa "terdapat dua alur pembinanan dan pengembangan profesi guru, yaitu: pembinaan dan pengembangan profesi, dan pembinaan dan pengembangan karir". Danim (2012: 10) mengungkapkan bahwa "kegiatan pembinaan dan pengembangan profesi dapat dilakukan oleh institusi pemerintah, lembaga pelatihan (training provider) non-pemerintah, penyelenggara, atau satuan pendidikan". Adapun bidang kajian dalam pembinaan dan pengembangan profesi guru meliputi pembinaan kompetensi pedagogis, kepribadian, sosial, dan profesional.

Kompetensi profesional merupakan salah satu kompetensi yang paling penting bagi guru. Danim (2012: 29) menjelaskan bahwa "kompetensi profesional yaitu kemampuan 
yang harus dimiliki guru dalam perencanaan dan pelaksanaan proses pembelajaran". Aktivitas pembelajaran yang semakin kompleks menyebabkan guru harus mampu memenuhi kebutuhan peserta didik. Oleh karena itu, dalam merencanakan dan melaksananakan proses pembelajaran, guru dituntut memiliki kompetensi profesional yang baik agar dapat memenuhi kebutuhan peserta didiknya. Adapun kemampuan yang harus dimiliki oleh guru pada dimensi kompetensi profesional sebagaimana dinyatakan dalam Peraturan Menteri Pendidikan Nasional Nomor 16 Tahun 2007 tentang Standar Kualifikasi Akademik dan Kompetensi Guru.

Sejatinya setiap disiplin ilmu yang diberikan kepada peserta didik mengalami peningkatan secara continue, sehingga apa yang diberikan kepada peserta didik mengalami peningkatan tingkat kesulitan karena materi yang diberikan adalah materi baru. Akan tetapi realita yang saat ini terjadi adalah pembelajaran penjas yang masih tradisional, yaitu kegaiatan pembelajaran yang berorientasi pada kecabangan dan kesenangan peserta didik tanpa memperhatikan tujuan yang hendak dikembangkan serta tidak melakukan modifikasi. Tradisionalnya pembelajaran penjas tersebut terjadi di setiap jenjang pendidikan.Misalnya pembelajaran penjas pada tingkat sekolah menengah atas (SMA), hampir semua materi yang diberikan kepada peserta didik merupakan pengulangan dari materi pembelajaran penjas di sekolah dasar (SD). Kondisi seperti ini terjadi hampir diseluruh daerah di Indonesia, termasuk di daerah Kota Yogyakarta. Sebagian besar guru-guru penjas di daerah tersebut masih memberikan materi yang itu-itu saja dalam pembelajaran penjas. Kurangnya upaya guru penjas dalam meningkatkan keprofesionalan tentu tidak semata-mata kesalahannya. Di sinilah pentingnya peran institusi atau dinas pendidikan dalam mengawasi dan membantu upaya pengembangan keprofesionalan guru penjas. Dinas pendidikan Kota Yogyakarta maupun lembaga pendidikansaat inibelum mengawasikegiatan pembelajaran penjas dengan optimal. Dinas pendidikan cenderung lebih mengawasi aktivitas kegiatan pembelajaran yang ada di dalam ruangan kelas. Banyak aktivitas pembelajaran penjas yang tidak terpantau dengan baik sehingga menyebabkan kurang disiplinnya guru penjas dalam melakukan upaya pengembangan diri maupun kualitas kegiatan pembelajaran.

\subsection{Kajian Pustaka}

\section{Manajemen Sumber Daya Manusia}

\section{a. Pengertian Manajemen Sumber Daya Manusia}

Manajemen menurut Sapre (Usman, 2014: 6) adalah "serangkaian kegiatan yang diarahkan langsung untuk penggunaan sumber daya organisasi secara efektif dan efisien dalam rangka mencapai tujuan organisasi". Usman (2014: 6) menjelaskan bahwa "manajemen adalah perencanaan, pelaksanaan, dan pengawasan (P3) sumber daya organisasi untuk mencapai tujuan secara efektif dan efisien". Tim dosen UPI (2012: 230) menjelaskan bahwa "manajemen adalah bekerja dengan orangorang untuk mencapai tujuan organisasi dengan pelaksanaan fungsi-fungsi perencanaan (planning), pengorganisasian (organizing), penyusunan personalia (staffing), pengarahan dan kepemimpinan (leading) dan pengawasan (controlling)".

Dari beberapa definisi diatas dapat disimpulkan bahwa manajemen sumber daya manusia adalah suatu rangkaian kegiatan yang dilakukan oleh sekelompok manusia guna mencapai tujuan bersama dengan memaksimalkan fungsi-fungsi manajemen seperti perencanaan, pengorganisasian, penyusunan staf, pengarahan, kepemimpinan serta pengawasan dalam mengembangkan bakat seseorang secara efektif dan efisien.

\section{Manajemen Pendidikan Nasional Konsep Manajemen Pendidikan}

Manajemen pendidikan Indonesia tentunya tidak terlepas dari tujuan pendidikan Indonesia itu sendiri. Adapun tujuan 
pendidikan Indonesia yaitu mengembangkan kemampuan dan membentuk watak serta peradaban bangsa yang bermartabat dalam rangka mencerdaskan kehidupan bangsa, bertujuan untuk berkembangnya potensi peserta didik agar menjadi manusia yang beriman dan bertaqwa kepada Tuhan Yang Maha Esa, berakhlak mulia, sehat, berilmu, cakap, kreatif, mandiri dan menjadi warga negara yang demokratis serta bertanggung jawab (UU No. 20 tahun 2003). Usman (2014: 13) menjelaskan bahwa "manajemen pendidikan adalah seni dan ilmu mengelola sumber daya pendidikan untuk mewujudkan proses dan hasil belajar peserta didik secara aktif, kreatif, inovatif, dan menyenangkan dalam mengembangkan potensi dirinya”.

Tujuan pendidikan akan tercapai secara efektif dan efisien jika proses manajemennya dilakukan dengan baik. Tim Dosen UPI (2012: 88) mengatakan bahwa "Dilakukan manajemen agar pelaksanaan suatu usaha terencana dan sistematis dan dapat dievaluasi secara benar, akurat dan lengkap sehingga mencapai tujuan secara produktif, berkualitas, efektif dan efisien".

\section{Pengembangan SDM/Profesionalme Guru a. Konsep Pengembangan Profesionalisme Guru}

Rebore (Farihah \& Ghani, 2011: 56) mengemukakan bahwa ciri-ciri profesionalisme guru bisa ditinjau dari enam komponen, yaitu:
1) Pemahaman dan penerimaan dalam melaksanakan tugas
2) Kehendak melakukan kerjasama secara efektif dengan pelajar, guru, orangtua pelajar, dam masyarakat

3) Kemampuan mengembangkan visi dan pertumbuhan jabatan secara berterusan

4) Mengutamakan pelayanan saat tugas

5) Mengarahkan, menekan, dan menumbuhkan pola perilaku belajar

6) Melaksanakan kode etik jabatan.

Upaya pengembangan yang dilakukan oleh guru tentu harus berdampak pada peningkatan kemampuannya. Salah satu bentuk peningkatan kemampuan guru bisa ditinjau dari kemampuannya dalam kegiatan belajar mengajar, karena jangan sampai guru tersebut keliru dalam melakukan fungsi dan perannya sebagai pendidik. Tujuan Pengembangan Profesionalisme Guru Guskey (Parwazalam et al. 2011: 29) menjelaskan pengembangan

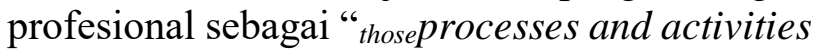
designed to enhance the professional knowledge, skill, attitudes of educators so that they might, in turn, improve the learning of students. In some cases, it also involves learning how to redesign educational structure and cultures". Pendapat tersebut menjelaskan bahwa suatu proses atau kegiatan yang dirancang untuk meningkatkan pengetahuan mengenai keprofesian, keterampilan, dan sikap pendidik yang pada akhirnya akan meningkatkan pembelajaran siswa.

\section{b. Tanggung Jawab Pengembangan Profesionalisme Guru}

Setiap guru pada dasarnya harus mampu menjadi profesional atau berkualitas. Hal inibertujuan untuk menghindari kesalahankesalahan atau malapraktik dalam kegiatan pembelajaran. Malapraktik dalam dunia pendidikan sampai saat ini masih sering terjadi. Misalnya masih ada guru yang mengajar tetapi tidak sesuai dengan bidang keahliannya. Danim (2011: 17) mengatakan bahwa "Malapraktik di dunia pendidikan agaknya dapat ditafsirkan sebagai penyimpangan perilaku guru, baik secara pedagogis, kepribadian, sosial, maupun akademik atau substansi yang diajarkan". Pandangan tersebut secara eksplisit menegaskan pentingnya peran guru dalam melakukan perubahan di sekolah.Keterlibatan guru sangat menentukan keberhasilan kegiatan belajar dan mengajar. Pengembangan sumber daya manusia yang diberdayakan terhadap guru-guru mampu memberikan pengaruh yang besar terhadap kualitas diri maupun secara kolektif dalam mencapai tujuan sekolah. Semua guru memiliki hak yang sama untuk mengikuti kegiatan pengembangan profesi. Akan tetapi, karena banyaknya kebutuhan yang harus dipenuhi oleh institusi atau dinas pendidikan menyebabkan tidak semua guru memiliki kesempatan untuk mengukuti pembinaan dan pengembangan. Oleh 
karena itu, guru harus memiliki inisiatif untuk mengembangkan kemampuan diri secara mandiri.

\section{c. Kebijakan Pengembangan Profesi Guru}

Dalam Undang-Undang Nomor 14 Tahun 2007 tentang Guru dan Dosen disebutkan bahwa guru adalah pendidik profesional dengan tugas utama mendidik, mengajar, membimbing, mengarahkan, melatih, menilai, dan mengevaluasi perserta didik pada pendidikan anak usia dini jalur pendidikan formal, pendidikan dasar, dan pendidikan menengah. Pengakuan atas keberadaan guru sebagai tenaga profesional bertujuan untuk mengangkat martabat dan peran guru sebagai agen pembelajaran untuk meningkatkan mutu pendidikan nasional. Pendidikan yang berkualitas sangat membutuhkan keberadaan guru yang profesional. Oleh karena itu, program pembinaan dan pengembangan guru sangat diperlukan sebagai upaya untuk meningkatkan profesinalismenya. Dari pendapat tersebut dapat dipahami bahwa pendanaan dalam pendidikan merupakan tanggungjawab bersama diantara pemerintah pusat dan daerah. Oleh karena itu, diperlukan adanya komitmen dan kesepakatan bersama diantara pemilik kepentingan untuk bersama-sama memajukan pendidikan.

\section{Metode Penelitian}

Penelitian ini menggunakan metode penelitian kualitatif dengan jenis studi kasus. Alasan pemilihan metode penelitian kualitatif dengan pendekatan studi kasus agar mendapatkan data yang mendalam dan mengungkapkan informasi tentang manajemen pengembangan profesionalisme guru penjas sekolah menengah atas (SMA) negeri di Kota Yogyakarta berdasarkan sudut pandang subjek penelitian pada setting yang alamiah.

Penelitian ini dilaksanakan di Kota Yogyakarta. Pelaksanaannya dilakukan di forum MGMP penjas Kota Yogyakarta. Alasan pemilihan forum MGMP penjas Kota Yogyakarta didasarkan atas pertimbangan bahwa upaya pengembangan yang dilakukan kepada guru penjas di Kota Yogyakarta sampai saat ini hanya terfokus pada kegiatan MGMP. Sementara itu, pemilihan pengawas mata pelajaran penjas didasarkan atas pertimbangan bahwa pengawas mata pelajaran merupakan orang yang paling mengetahui keadaan riil profesionalisme guru penjas di lapangan karena dalam kesehariannya bertugas untuk membina dan membimbing guru penjas.

Waktu penelitian dilakukan dalam tiga tahap, yaitu: tahap persiapan, tahap pengumpulan data, dan tahap pengecekan data. Penelitian ini dilaksanakan selama tiga bulan, yaitu bulan Januari 2017 sampai Maret 2017.

Subjek penelitian ini adalah Koordinator dan Ketua MGMP Penjas Kota Yogyakarta. Koordinator MGMP Penjas sebagai pimpinan organisasi dan tidak terikat pada periode kepemimpinan dijadikan sebagai key informan. Ketua MGMP Penjas dipilih sebagai informan karena terlibat langsung dalam program pengembangan keprofesionalan.

Objek penelitian dalam penelitian ini adalah manajemen pengembangan kompetensi profesional guru penjas sekolah menengah atas (SMA) Negeri di Kota Yogyakarta. Adapun manajemen pengembangan kompetensi profesional yang diteliti mencakup (1) kondisi profesionalisme; (2) perencanaan program pengembangan; (3) pelaksanaan program pengembangan; (4) pelaksanaan evaluasi kegiatan pengembangan.

Teknik pengumpulan data yang digunakan dalam penelitian ini adalah wawancara yang dilakukan secara terstruktur menggunakan pedoman wawancara meski pada pelaksanaannya terkadang tidak mengenai pokok penelitian, tetapi tetap mengacu pada pedoman wawancara agar hasil wawancara tetap memenuhi dan sesuai dengan kebutuhan penelitian. Wawancara dilaksanakan setelah peneliti membuat janji terlebih dahulu dengan subjek penelitian.

Instrumen pengumpulan data dalam penelitian kualitatif adalah peneliti itu sendiri yang menggunakan instrument pendukung berupa pedoman wawancara, pedoman 
observasi, dan pedoman analisis dokumen. Pedoman wawancara merupakan sejumlah pertanyaan yang peneliti buat untuk ditanyakan kepada informan. Pertanyaan tersebut ditujukan untuk mengungkapkan dan menjelaskan sudut pandang informan terkait pengembangan guru penjas di Kota Yogyakarta. Pedoman observasi berisi daftar dokumen yang di analisis untuk melengkapi pengumpulan data mengenai program-program pengembangan keprofesian guru penjas SMA Negeri di Kota Yogyakarta.

Dalam melakukan analisis data kualitatif bertujuan pada proses penggalian makna, penggambaran, penjelasan, dan penempatan data pada konteknya masingmasing. Uraian data jenis ini berupa kalimatkalimat, bukan angka atau tabel-tabel. Untuk itu data yang diperoleh harus diorganisir dalam bentuk struktur yang mudah dipahami dan diuraikan. Data dalam penelitian ini dikumpulkan menggunakan QSR NVivo Plus 11 dari Tom Richards dan Lyn Richards (2012).

\section{Hasil dan Diskusi}

Data penelitian tentang upaya untuk menggali tingkat pada pengembangan profesionalisme guru pada kompetensi profesional guru penjas tingkat sekolah menengah atas (SMA) negeri di Kota Yogyakarta yang meliputi perencanaan, pelaksanaan, dan evaluasi ini diperoleh dengan observasi, wawancara dan dokumentasi. Setelah data terkumpul, maka dilakukan analisis data. Analisis data dalam penelitian ini dibantu dengan menggunakan software QSR NVivo 11. Hal pertama yang dilakukan untuk menganalisis data hasil dari lapangan adalah dengan memasukkan data kedalam software NVivo 11 atau biasa disebut input data.

Analisis data dengan membandingkan topik-topik yang telah dibuat dengan jawaban informan kunci. Topik-topik atau transkrip dibuat berdasarkan garis besar jawaban informan kunci dari hasil wawancara. Setiap pertanyaan memiliki data transkrip tersendiri yang nantinya menjadi topik utama dalam pembahasan. Namun sebelum menganalisisnya, dapat dibuat mind mapping atau peta topiktopik utama yang dibuat melalui software N-Vivo 11.

Bahwa permasalah utama yaitu profesionalisme guru penjas berdasarkan hasil wawancara informan kunci dapat diambil topik-topik utama yang berpengaruh terhadap profesionalisme guru penjas diantaranya, (1) Kondisi profesionalisme guru penjas di Kota Yogyakarta (2) Bentuk program yang akan dilaksankaan; (3) Faktor penghambat pengembangan; (4) Langkah yang ditempuh dalam menghadapi hambatan; (5) Pengaruh program pengembangan; (6) Bagaimanakah program-program yang telah dilaksanakan tim MGMP Kota Yogyakarta. Apabila dijabarkan per sub topik maka akan terlihat jawaban terperinci dari setiap informan kunci.

Matrix coding query digunakan untuk membandingkan data hasil wawancara dibandingkan dengan status demografi dari informan. Dalam hal ini peneliti akan membandingkan status jabatan dengan jawaban dari hasil wawancara. Perbandingan pertama adalah terkait pertanyaan tentang kondisi profesionalisme guru penjas di Kota Yogyakarta yang dapat dilihat pada grafik 1 .

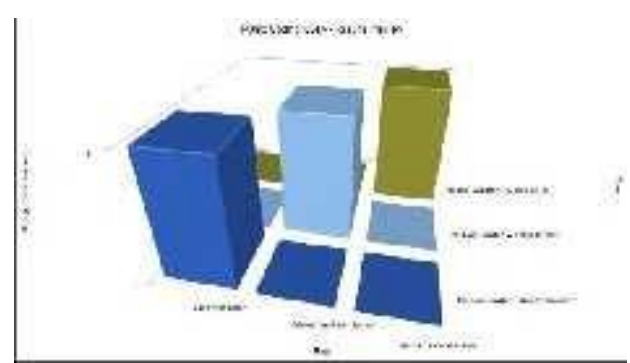

\section{Grafik 1. Profesionalisme Guru Penjas di Kota Yogyakarta Menurut Informan}

Dari grafik di atas dapar di lihat bahwa menurut Kepala Sekolah, profesionalisme guru penjas ada pada cara mengajarnya. Lebih lengkapnya bahwa cara mengajar guru penjas masih menggunakan metode konvensional, hal ini terbentuk Karena sudah terbiasa dengan kondisi mengajar konvensional sehingga sudah menemukan zona nyaman dalam mengajar konvensional. Menurut Ketua MGMP profesionalisme guru penjas ada pada lemahnya administrasi. Lebih lengkapnya adalah bahwa 
administrasi guru penjas ada pada pembuatan PTK. Guru penjas lemah dalam membuat PTK, apabila ada hanya menggunakan perangkat yang seperti itu-itu saja tidak ada pengembangan. Sedangkan menurut guru penjas, profesionalisme guru penjas di Kota Yogyakarta adalah ada pada kurangnya sarana dan prasarana. Kondisi sarana dan prasarana yang dimiliki sekolah masih dirasa kurang membuat guru kesulitan dalam mengajar.

Perbandingan kedua adalah terkait pertanyaan tentang program pengembangan yang telah dilaksanakan pada guru penjas di Kota Yogyakarta yang dapat dilihat pada grafik 2 .

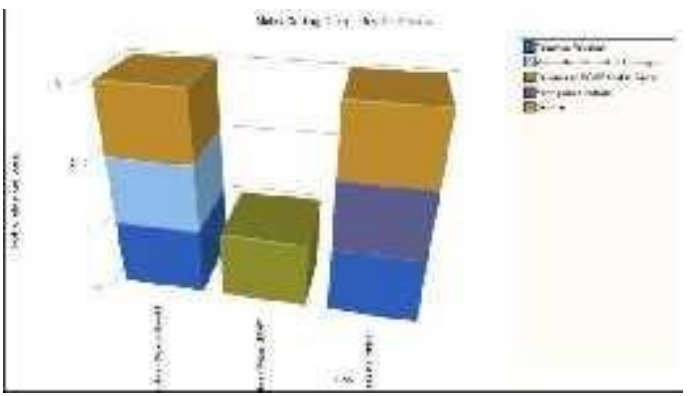

\section{Grafik 2. Program Pengembangan Profesionalisme Guru Penjas Menurut Informan}

Dari grafik di atas dapat dilihat bahwa menurut Kepala Sekolah program pengembangan yang telah dilakasanakan MGMP Penjas di Kota Yogyakarta adalah pada pengadaan Pelatihan-pelatihan yaitu berupa pelatihan wasit cabang olahraga agar pada saat siswa sedang mengikuti perlombaan guru penjas tau akan peraturannya, kemudian pemecahan masalah di lapangan dengan mencari solusi bersama pada pertemuan MGMP, yang terakhir adalah pengadaan seminar-seminar keolahragaan agar guru penjas rajin menulis. Kemudian menurut Ketua MGMP adalah pada pengadaan MGMP di tingkat rayon. Karena dengan diadakannya pertemuan MGMP tingkat rayon, masalah paling kompleks dapat diatasi bersama. Sedangkan menurut guru penjas adalah pada pada pelatihanpelatihan yaitu berupa pelatihan menulis PTK, kemudian memberikan motivasi kepada guru penjas agar lebih kreatf dan inovatif dalam mengajar, dan yang terakhir adalah mengikuti seminar-seminar dan studi kasus di lapangan.
Perbandingan ketiga adalah terkait pertanyaan tentang bagaimana pengaruh program pengembangan pada guru penjas di Kota Yogyakarta yang dapat dilihat pada grafik 3.

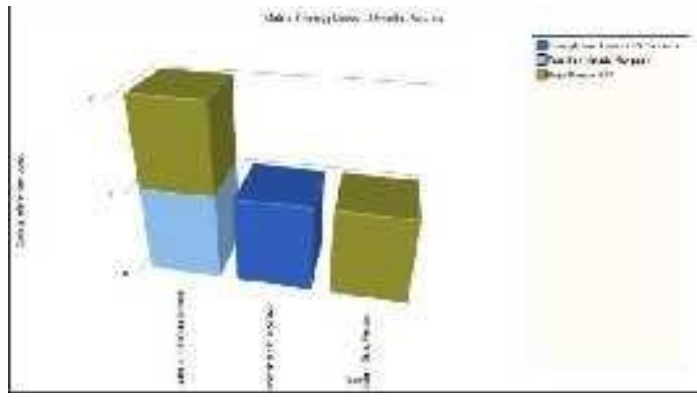

\section{Grafik 3. Pengaruh Program Pengembangan pada Guru Penjas Menurut Informan}

Dari grafik di atas dapat dilihat bahwa menurut Kepala Sekolah bahwa pengaruh program pengembangan ada pada peralihan metode mengajar bahwa ada peningkatan dari yang sebelumnya menggunakan metode konvensional kini mulai beralih menggunakan metode yang baru, kemudian ada pada peningkatan dalam hal menulis PTK. Menurut Ketua MGMP adalah adanya peningkatan dalam hal administrasi seperti rajin menulis, membuat RPP, membuat PTK. Namun apabila hal ini tidak dipantau, maka pola lama akan kembali. Sedangkan menurut guru penjas adanya program pengembangan yang dilakukan menjadikan adanya pengaruh pada peningkatan guru dalam menulis PTK.

Perbandingan keempat adalah terkait bagaimana bentuk program pengembangan yang akan dilaksanakan pada guru penjas di Kota Yogyakarta yang dapat dilihat pada grafik 4 .

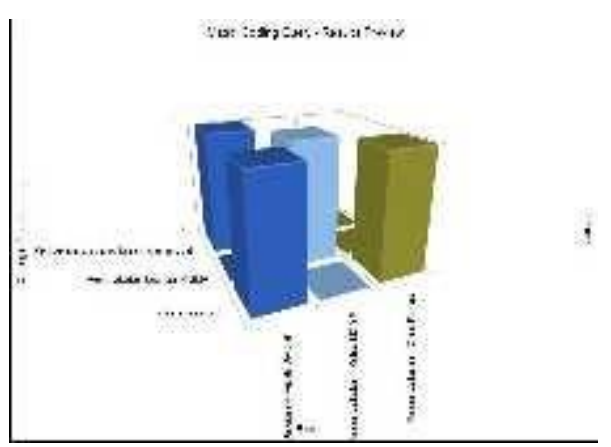

Grafik 4. Bentuk Program Pengembangan yang akan dilaksanakan Menurut Informan

Dari grafik di atas dapat dilihat bahwa 
menurut Kepala Sekolah terkait bagaimana bentuk program pengembangan yang akan dilaksanakan adalah pada pembelajaran yang kreatif dan inovatif dan pelaksanaan sosialisasi K13. Pada pembelajaran yang kreatif dan inovatif adalah bahwa sebuah keterbatasan sarana dan prasaran menjadi penghambat dalam proses pembelajaran, guru harus dapat berinovasi agar tujuan dari pembelajaran dapat tercapai. Kemudian dengan mengadakan sosialisasi K13 adalah agar guru mampu mengisi kebutuhan guru penjas di masa mendatang. Kemudian menurut Ketua MGMP bentuk program pengembangan yang akan dilaksanakan adalah dengan peningkatan kualitas MGMP. Guru penjas harus aktif dalam kegiatan MGMP, karena dari situlah permasalahan di lapangan akan dibahas dan dipecahkan secara bersamasama. Sedangkan menurut guru penjas bahwa bentuk program pengembangan yang akan dilaksanakan adalah pada sosialisasi K13. Sosialisasi K13 diperlukan dikarenakan masih banyak guru penjas yang belum melaksanakan tugas dan fungsi dasar seorang guru. Pembelajaran yang diterapkan masih menggunakan metode konvensional. Dengan sosialisasi K13, guru akan beralih metode mengajar dari konvensional menjadi metode yang sesuai dengan kurikulum K13.

Perbandingan kelima adalah terkait apa saja yang menjadi faktor yang menjadi penghambat dalam proses pengembangan profesionalisme guru penjas di Kota Yogyakarta dapat dilihat pada grafik 5 .

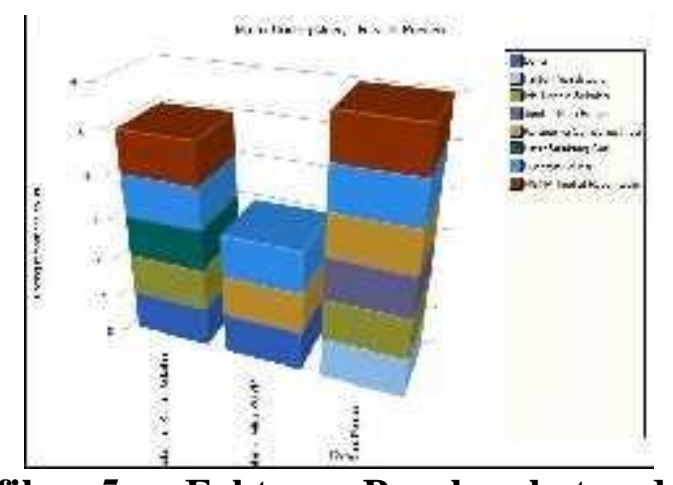

Grafik 5. Faktor Penghambat dalam Pengembangan Profesionalisme Menurut Informan

Dari grafik di atas dapat dilihat bahwa menurut kepala sekolah banyak faktor yang menjadi penghambat dalam proses pengembangan profesionalime guru penjas, diantaranya adalah MGMP tingkat rayon belum maksimal, luasnya lokasi, latar belakang setiap guru berbeda, dana yang dibutuhkan lebih besar dibandingkan yang didapat. Menurut Ketua MGMP faktor-faktor yang menjadi penghambat dalam pengembangan profesionalisme guru penjas di Kota Yogyakarta adalah pada faktor pribadi guru itu sendiri, motivasi yang didapatkan guru berkurang ketika guru membawa siswanya menjadi juara, namun penghargaan dari dinas tidak ada. Kemudian kurangnya sumbangan dana menjadi salah satu penyebab utama dalam pengembangan profesionalisme guru penjas, hal ini dikarenakan tidak adanya asupan dana dari dinas kota. Alasan terakhir adalah kurangnya sumbangsih yang diberikan guru penjas dalam mengikuti kegiatan-kegiatan MGMP. Sedangkan menurut guru penjas faktor-faktor penghambat dalam pengembangan profesionalisme guru penjas adalah MGMP tingkat rayon yang belum terbentuk secara maksimal, luasnya lokasi, kurangnya sumbangsih guru penjas dalam mengikuti kegiatan MGMP, jumlah guru penjas yang masih kurang di sekolah-sekolah yang mengakibatkan tidak adanya pengganti guru saat guru penjas yang bersangkutan sedang tugas di luar. Selain itu izin dari kepala sekolah yang terlalu sulit atau bahkan di persulit membuat setiap ada kegiatan MGMP di luar susah untuk diikuti. Kemudian yang terakhir adalah faktor pribadi guru itu sendiri, guru masih malas untuk menulis PTK, padahal dalam aturan jelas disebutkan bahwa guru harus mampu menulis PTK.

Perbandingan keenam adalah terkait apa saja langkah yang ditempuh untuk mengatasi hambatan profesionalisme guru penjas di Kota Yogyakarta terdapat pada grafik 6. 


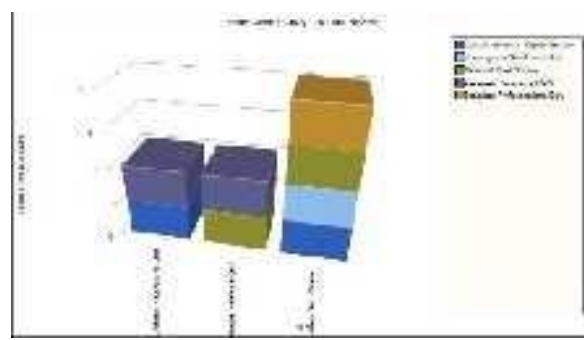

Grafik 6. Langkah yang di Tempuh Untuk Mengatasi Hambatan Menurut Informan

Dari grafik di atas dapat dilihat bahwa menurut Kepala Sekolah langkah-langkah yang ditempuh untuk mengatasi hambatan profesionalisme guru penjas di Kota Yogyakarta adalah dengan sosialisasi pentingnya MGMP, karena dengan adanya MGMP maka masalah guru penjas dapat dibahas bersama untuk mencari solusinya. Selain itu ada pula dengan memberikan pengertian kepada Kepala Sekolah akan pentingnya manfaat dari pendidikan jasmani untuk peserta didik. Dengan memberikan sarana dan prasaran, dimudahkan dalam kegiatan di luar sekolah, dan dipermudah dalam pendanaannya. Kemudian menurut Ketua MGMP menuturkan langkah-langkah yang telah diambil adalah dengan dibuat MGMP tingkat rayon, bahkan jika perlu dibuat sub-sub rayon agar pengawasanna menjadi lebih mudah. Faktor luasnya wilayah Kota Yogyakarta menjadikan susahnya dalam pengawasan dan pembinaan.

\section{Simpulan}

Berdasarkan hasil penelitian di atas secara keseluruhan diketahui bahwa kondisi profesionalisme guru penjas di Kota Yogyakarta tidak bisa dikatakan tinggi, hal ini karena masih banyak ditemukan permasalahan yang mempengaruhi tingkat profesionalisme guru penjas di Kota Yogyakarta, diantaranya adalah sarana dan prasarana yang belum memadai, metode mengajar yang masih banyak menggunakan metode konvensional, dan kelemahan administrasi. Dari berbagai kegiatan yang telah dilaksanakan tim MGMP Kota Yogyakarta, profesionalisme guru penjas di Kota Yogyakarta membawa banyak pengaruh, diantaranya ada pada peralihan metode mengajar dari tradisional menjadi pembelajaran inovatif, guru menjadi rajin menulis PTK dan peningkatan dalam administrasi.

\section{Daftar Pustaka}

Danim, S. (2011). Pengembangan profesi guru dari pra-jabatan, induksi ke profesional madani. Jakarta: Kencana Prenada Media Group.

Depdiknas. (2007). Peraturan menteri pendidikan nasional Republik Indonesia Nomor 16 Tahun 2007 Tentang Standar Kualifikasi Akademik dan Kompetensi Guru.

(2003). Undang-Undang Nomor 20 Tahun 2003 Tentang Sistem Pendidikan Nasional.

Nomor $\begin{gathered}\text { (2003). } \\ \text { Guru dan Dosen. }\end{gathered}$ Undang-Undang
Guru 2005 Tentang
Nomor 74 Tahun 2005 tentang Guru.

